\title{
PENTINGNYA BAHASA ARAB BAGI UMAT ISLAM DI PEDESAAN
}

\author{
Moh. Aziz Arifin \\ UIN Maulana Malik Ibrahim Malang \\ azarifin@gmail.com \\ Sukandar \\ Universitas Islam Kadiri Kediri \\ sukandar@uniska-kediri.ac.id
}

\section{Abstrak}

Bahasa Arab adalah bahasa yang terpilih sebagai yang digunakan dalam al-Qur'an dan Hadis. Oleh karena itu, bahasa Arab sering disebut sebagai ilmu alat khususnya dalam memahami agama bagi umat Islam di seluruh dunia. Penelitian ini bertujuan untuk mengetahui pentingnya bahasa Arab bagi umat Islam di pedesaan Desa Ngreco, Kecamatan Kandat, Kabupaten Kediri. Metode yang digunakan dalam penelitian ini adalah metode penelitian kualitatif dengan beberapa tahapan yang telah ditentukan. Hasil dari penelitian ini menunjukkan bahwa bahasa Arab bagi umat Islam di pedesaan Desa Ngreco Kecamatan Kandat Kabupaten Kediri sudah dikenalkan sejak dini kepada anak-anak mereka. Hal ini karena bahasa Arab dipahami sebagai ilmu dasar untuk mempelajari dan memahami kitab-kitab yang semuanya menggunakan bahasa Arab, tidak hanya al-Qur'an dan Hadis. Sedangkan kitab-kitab tersebut merupakan pedoman yang digunakan oleh umat Islam untuk mempelajari pengetahuan ilmu agama. Selain itu, penelitian ini juga mengungkapkan bahwa tradisi anak-anak mempelajari bahasa Arab sejak dini di pedesaan Desa Ngreco, Kecamatan Kandat, Kabupaten Kediri, sudah dilaksanakan secara turun-temurun karena orang tua mereka juga melakukan hal itu serupa oleh generasi sebelumnya.

Kata Kunci: Bahasa Arab, Umat Islam, Pedesaan, Pengetahuan Agama. 


\section{Abstract}

Arabic is the language chosen as the language used in the Qur'an and Hadith. Therefore, Arabic is often referred to as a science tool, especially in understanding religion for Muslims around the world. This study aims to determine the importance of Arabic for Muslims in rural areas of Ngreco Village, Kandat District, Kediri Regency. The method used in this research is a qualitative research method with several predetermined stages. The results of this study indicate that Arabic for Muslims in rural areas of Ngreco Village, Kandat District, Kediri Regency has been introduced early to their children. This is because Arabic is understood as the basic knowledge for studying and understanding books which all use Arabic, not only the Qur'an and Hadith. While these books are guidelines used by Muslims to study religious knowledge. In addition, this research also reveals that the tradition of children learning Arabic from an early age in the village of Ngreco Village, Kandat District, Kediri Regency has been carried out from generation to generation because their parents have also done the same thing by previous generations.

Keywords: Arabic, Muslim, Countryside, Religious Knowledge.

\section{Pendahuluan}

Islam merupakan agama rahmatan lil 'alamin, agama yang dapat diterima di seluruh kalangan baik orang miskin, kaya, perkotaan, pedesaan, perantauan, dan dalam profesi apapun, baik laki-laki beragama Islam yang disebut Muslim maupun perempuan beragama Islam disebut Muslimah.

Agama Islam adalah agama dari Allah yang diturunkan kepada umat manusia yang dibawa melalui utusanNya yang menjadi rasul dan nabi yang terakhir, yaitu Nabi Muhammad Saw. sebagai penyempurna dari ajaran agama yang sebelumnya disampaikan oleh para nabi dan rasul. Allah Swt. berfirman:

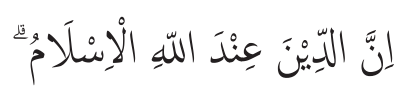

Sesungguhnya agama (yang diridhai) di sisi Allah hanyalah Islam (QS. Ali Imran [3]: 19).

Hal inilah yang menjadikan Agama Islam disebut agama terakhir yang merupakan penyempurna dari agama sebelum Islam.

Dalam masyarakat pedesaan yang beragama Islam di wilayah Jawa khususnya, masyarakat seringkali mengintegrasikan kebudayaan setempat dengan agama. Perubahan kebudayaan dan peradaban memang sesuatu yang mungkin terjadi karena perubahan zaman, terlebih lagi agama Islam mengatur dan 
menata segala kehidupan, dan kebudayaan yang terkandung di dalamnya. Islam masuk ke wilayah Jawa, dengan Islam masuk ke wilayah Jawa menimbulkan paduan budaya Jawa dengan ajaran Islam, karena Islam diterima di wilayah Jawa dengan cara budaya Jawa dan ajaran Islam dimasukkan di dalamnya seperti wayang, ketoprak, sastra, arsitektur, dan sebagainya.

Paduan antara agama Islam dan kebudayaan Jawa sudah ada sejak agama Islam masuk ke tanah Jawa, karena dakwah Islam di Jawa dilakukan melalui kebudayaan Jawa yang budaya tersebut dimasukkan ajaran-ajaran Islam. Pada era kerajaan yang ada di tanah Jawa yang sebelumnya beragama Hindu dan Budha beralih menjadi kerajaan Islam, hal ini dibuktikan dengan peninggalanpeninggalan berupa seni ukir, sastra, wayang, bangunan masjid, pola pemakaman, seni arsitektur dan sebagainya. Hasil yang diperoleh dengan adanya kombinasi Islam dan budaya Jawa dapat menanamkan nilai-nilai keislaman pada masyarakat Jawa. ${ }^{1}$

Dalam sejarah perkembangan di pulau Jawa, khususnya adat istiadat yang bernuansa pedesaan adalah ciri khas dari perkembangan agama Islam pada masa itu.

1 Donny Khoirul Azis, "Akulturasi Islam dan Budaya Jawa," Fikrah: Jurnal Ilmu Aqidah dan Studi Keagamaan 1, no. 2 (2013), https:// doi.org/10.21043/fikrah.v1i2.543.
Selain perkembangan agama Islam dengan kebudayaan dan adat istiadat Jawa dalam penelitian ini juga akan membahas tentang faktor bahasa Arab juga merupakan hal terpenting dalam mendalami agama Islam di Indonesia khususnya pulau Jawa.

Menurut al-Ghalayini, bahasa Arab yaitu kalimat-kalimat yang digunakan oleh orang Arab untuk menyampaikan maksud dan tujuan (pikiran dan perasaan) mereka. ${ }^{2}$

Bahasa Arab yaitu bahasa paling dari segi jumlah penutur dalam keluarga bahasa Semitik. Bahasa Arab adalah kalimat yang digunakan oleh orang Arab untuk mengutarakan maksud dan tujuan mereka. Yang berbentuk huruf hijaiyah yang dipergunakan oleh orang Arab dalam berkomunikasi dan berinteraksi sosial baik secara lisan maupun tulisan. Setiap Bahasa adalah komunikatif bagi para penuturnya. Apabila ditinjau dari aspek ini, maka bahasa itu mempunyai fungsi dan manfaat yang sama tanpa ada pembeda antara bahasa satu dengan bahasa lainnya, karena fungsi dari bahasa adalah untuk alat komunikasi yang digunakan untuk bertukar pikiran satu dengan yang lainnya. Dari sinilah fungsi dari pada bahasa digunakan yaitu yang menyampaikan maksud tujuan pembicara dapat dite-

2 Mustafa al-Ghalayin, Jami' ad-Durus al-'Abiyah, Jilid 1 (Beirut: Dar al-Kutub al'Ilmiyah, 2005), 7. 
rima oleh pendengar sehingga maksud dan tujuan bahasa tercapai. Bahasa di Negara Indonesia adalah bahasa Indonesia. Namun, dengan mayoritas warga negara Indonesia adalah muslim, bahasa Arab adalah bahasa terpenting setelah bahasa Indonesia.

Bahasa Arab di Indonesia mulai berkembang ketika orang indonesia masuk Islam. Karena setelah orang masuk agama Islam secara otomatis akan belajar bahasa Arab. Karena bahasa Arab dipelajari sebagai alat mendalami Islam secara menyeluruh. Hal ini membuktikan bahwa tujuan warga Indonesia mempelajari bahasa Arab tidak lain adalah untuk mempelajari lebih dalam pengetahuan tentang Islam sebab kebanyakan kitab-kitab Islam tersebut semua menggunakan bahasa Arab.

Amanah mengemukakan bahwa bahasa Arab bukan hal yang asing bagi umat Islam. Mayoritas muslim di Indonesia belajar bahasa Arab dimulai dari pendidikan pra sekolah hingga perguruan tinggi bahkan orang yang tidak berpendidikan formal pun juga belajar bahasa Arab. Pada umumnya, tujuan belajar bahasa Arab adalah untuk memahami al-Qur'an dan Hadis karena untuk mempelajari keduanya mutlak dibutuhkan kemampuan memahami bahasa Arab. Selain itu, seorang muslim pada tingkatan yang khusyuk dalam ibadah dianjurkan untuk memahami setiap bacaan di dalam ibadah sholat, sehingga mampu melakukan ibadah secara khusyuk. ${ }^{3}$ Orang pedesaan biasanya mempelajari bahasa secara turun temurun dengan metode pengenalan bahasa juga dengan metode klasik.

Agama Islam mempunyai kitab suci al-Qur'an yang menjadi pedoman dan landasan hidup orang Islam atau muslim, selain al-Qur'an landasan yang kedua yaitu Hadis yang menjadi pedoman setelah al-Qur'an dari kedua pedoman semua menggunakan bahasa Arab. Selain al-Qur'an dan Hadis, juga terdapat kitab-kitab yang dikarang oleh ulama Islam yang menjadi penjelas dari al-Qur'an dan Hadis dan kebanyakan juga berbahasa Arab. Hal inilah menjadi penting bagi muslim untuk mendalami dan mempelajari bahasa Arab yang berhubungan dengan agama Islam, yakni agar seorang muslim menjadi arif dan bijaksana. ${ }^{4}$ Hal ini yang menjadi faktor utama umat Islam untuk belajar bahasa Arab sejak dini.

Pengenalan Bahasa Arab sejak dini membawa efek yang positif bagi anak, yaitu anak yang mempunyai kelebihan intelektual, kemampuan akademik, berbahasa dan sosial. Selain itu, anak

3 Laelatul Amanah, "Urgensi Pembelajaran Bahasa Arab dalam Pendidikan Islam," OSF Preprints (2019), https://doi.org/10.31219/osf. io/dqns6.

4 Asna Andriani, "Urgensi Pembelajaran Bahasa Arab dalam Pendidikan Islam," Ta’allum 3, no. 1 (2015): 39-56. 
memiliki kesiapan memasuki dunia yang nyata dengan berbagai bahasa dan budaya. ${ }^{5}$

Dari permasalahan tersebut, peneliti akan membahas tentang pentingnya bahasa Arab bagi umat Islam yang berada di pedesaan.

\section{Metode Penelitian}

Penelitian ini termasuk ke dalam kategori penelitian kualitatif. Penelitian ini dilakukan melalui beberapa tahap yang digunakan. Pertama, metode deskripsi ialah pemaparan yang sistematis, faktual, dan akurat mengenai bahasa Arab dan agama Islam di pedesaan Desa Ngreco Kecamatan Kandat Kabupaten Kediri. Kedua, metode interpretasi, di mana penulis menyelami isi buku dan sedapat mungkin menangkap arti dan makna yang dimaksud. Observasi dan wawancara diperlukan untuk menggali data mengenai bahasa Arab dan agama Islam di pedesaan Desa Ngreco Kecamatan Kandat Kabupaten Kediri. Adapun observasi dan wawancara dilakukan selama 2 bulan.

\section{Pembahasan}

Bahasa Arab adalah bahasa yang terpilih menjadi bahasa al-Qur'an dan

${ }^{5}$ Lutfi Ulfah Faridah, "Pengenalan Bahasa Arab untuk Anak Sejak Dini," Prosiding Konferensi Bahasa Arab III (Malang, 7 October 2017).
Hadis. Selain itu, bahasa Arab juga menjadi alat komunikasi di umat manusia khususnya di wilayah Timur Tengah. Sangat pentingnya bahasa Arab bagi umat Islam hal ini menjadi pemicu orang tua untuk mengenalkan bahasa Arab sejak dini kepada anak-anaknya.

Karena dalam penelitian yang dilakukan oleh Baroroh \& Pratiwi menjelaskan belum ada rumusan kebijakan dari instansi pemerintah (Kemendiknas atau Kemenag) yang mengatur mengenai pendidikan bahasa Arab bagi pendidikan anak usia dini. ${ }^{6}$

Desa Ngreco Kecamatan Kandat Kabupaten Kediri merupakan desa yang terletak di kecamatan kandat bagian utara perbatasan dengan Kota Kediri, Desa Ngreco Kecamatan Kandat Kabupaten Kediri masyarakatnya mayoritas beragama Islam para orang tua sejak kecil akan mendidik anaknya dengan mengenalkan huruf hijaiyah yang merupakan dasar mengenal bahasa Arab. Karena dalam melaksanakan kewajiban sholat wajib 5 waktu seluruh bacaan yang terdapat dalam ritual ibadah semua menggunakan bahasa Arab. Hal tersebut yang menjadi salah satu alasan mengapa semua orang yang beragama Islam sejak dini anak-anak mereka pasti dikenalkan dengan bahasa Arab.

6 R. Umi Baroroh \& Novera Pratiwi, "Kebijakan Pendidikan Bahasa Arab pada Anak Usia Dini di Raudhatul Athfal," Al-Mahāra 1, no. 1 (2015). 
Bahasa Arab merupakan bahasa alQur'an. Allah Swt. berfirman:

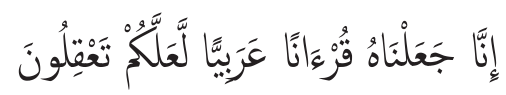

Sesungguhnya Kami telah menjadikan al-Qur'an dalam bahasa Arab supaya kalian memahaminya (QS. Yusuf [12]: 2).

Bahasa yang digunakan di dalam kitab suci al-Qur'an, kitabnya umat Islam, sudah cukup jelas bahwa semua tulisan adalah bahasa Arab. Bagaimana umat Islam tidak belajar bahasa Arab jika kitab yang dianutnya menggunakan bahasa Arab?

Selain al-Qur'an yang menjadi pokok atau pondasi umat Islam adalah Hadis, semua Hadis yang ditulis menggunakan bahasa Arab. Maka dari itu, semua umat Islam selain mempelajari al-Qur'an juga mempelajari Hadis yang menggunakan bahasa Arab.

Tradisi di pedesaan sejak dini sudah dikenalkan dengan huruf Hijaiyah dan dilanjutkan dengan mengaji iqro dari juz 1 sampai dengan juz 6 selain iqro ada juga kitab lama yang masih digunakan yang disebut dengan turutan. Kitab tersebut semua dimulai dengan huruf hijaiyah sampai dengan huruf yang bisa disambung dan huruf yang tidak bisa disambung. Setelah selesai (khatam) semua iqro 1-6 atau kitab turutan, berikutnya para murid baru dapat melanjutkan ke kitab alQur'an yang biasanya dimulai dari Juz 1 yaitu QS. al-Fatihah dan dilanjutkan QS. al-Baqarah sampai dengan QS. al-Ikhlas.

Selain itu, para murid di pedesaan juga belajar kitab-kitab yang mengenalkan bahasa Arab di antara kitab ro'sun, kitab tajwid, kitab tasrif. Kitabkitab dasar ini sebagai dasar murid sejak dini mengenal bahasa Arab dari beberapa kitab dasar tersebut.

Berdasarkan hasil pengamatan menunjukkan bahwa kebudayaan belajar bahasa Arab di pedesaan berjalan sesuai adat dan tradisi di pedesaan tersebut, apabila dibandingkan dengan pendidikan formal tradisi belajar bahasa Arab di pedesaan sejak dahulu dari sisi biaya sebenarnya tidak terlalu besar dan tidak membebani para muridnya, terkadang ada sebagian murid yang tidak melakukan pembayaran tetapi proses pembelajaran tetap berjalan seperti biasanya. ${ }^{7}$ Hal ini juga para ustaz sudah tertanam dalam diri untuk mengajarkan dasar agama Islam dengan keikhlasan, dengan sifat yang dimiliki oleh ustaz tersebut menjadikan proses pembelajaran dan berjalan secara continue.

Berdasarkan hasil dari wawancara dengan ustaz sekaligus informan dalam penelitian ini terdapat strategi pembelajaran bahasa Arab untuk meningkatkan

7 Observasi dilakukan pada 5 Januari 2021 di Desa Ngreco, Kecamatan Kandat, Kabupaten Kediri. 
pengetahuan tentang keislaman secara mendalam, yaitu dengan pengajaran yang fleksibel, maksudnya pembelajaran baca al-Qur'an untuk mencegah murid tidak takut belajar al-Qur'an yang berbahasa Arab seorang ustaz terkadang membenarkan sebagian saja yang salah walaupun terdapat beberapa kesalahan. Hal ini dilakukan karena murid supaya berani belajar secara terus-menerus dan menjadikan murid untuk memiliki rasa percaya diri yang tinggi. ${ }^{8}$ Di samping itu, pembelajaran bisa terus dilanjutkan tanpa diulang-diulang terus pada ayat tersebut, karena jika kurang lancar diulang-ulang terus akan membuat murid merasa bosan untuk belajar.

\section{Simpulan}

Dari pembahasan di atas, dapat disimpulkan bahwa bahasa Arab bagi umat Islam di pedesaan sangat penting. Hal ini ditunjukkan dengan pengenalan bahasa Arab sejak dini dan menjadi kebudayaan bagi masyarakat pedesaan Desa Ngreco, Kecamatan Kandat, Kabupaten Kediri, untuk belajar bahasa Arab karena bahasa Arab adalah kunci untuk mengenal agama Islam secara mendalam. Al-Qur'an dan Hadis yang merupakan dasar hukum agama Islam keduanya menggunakan bahasa Arab.

${ }^{8}$ Wawancara kepada K. Farhan Sirojul Munir di Kediri pada 7 Februari 2021.

\section{Daftar Pustaka}

Amanah, Laelatul. "Urgensi Pembelajaran Bahasa Arab dalam Pendidikan Islam.” OSF Preprints, 2019. https://doi.org/10.31219/osf.io/ dqns6.

Andriani, Asna. "Urgensi Pembelajaran Bahasa Arab dalam Pendidikan Islam." Ta'allum 3, no. 1 (2015): 39-56.

Azis, Donny Khoirul. "Akulturasi Islam dan Budaya Jawa." Fikrah: Jurnal Ilmu Aqidah dan Studi Keagamaan 1, no. 2 (2013). https://doi. org/10.21043/fikrah. v1i2.543.

Baroroh, R. Umi \& Novera Pratiwi. "Kebijakan Pendidikan Bahasa Arab pada Anak Usia Dini di Raudhatul Athfal." Al-Mahāra 1, no. 1 (2015).

Faridah, Lutfi Ulfah. "Pengenalan Bahasa Arab untuk Anak Sejak Dini.” Prosiding Konferensi Bahasa Arab III. Malang, 2017.

al-Ghalayin, Mustafa. Jami' ad-Durus al-Abiyah. Jilid 1. Beirut: Dar alKutub al-'Ilmiyah, 2005.

Munir, K. Farhan Sirojul. "Wawancara." Kediri, 7 Februari 2021. 
